\title{
Studies on pyrolytic conversion of waste plastic carry bags into plastic crude oil
}

\section{B. Prabha*, D. Ramesh and S. Kamaraj}

Department of Bioenergy, Agricultural Engineering College and Research Institute, Tamil Nadu Agricultural University, Coimbatore - 641003 (Tamil Nadu), INDIA

*Corresponding author. E-mail: prabha_026@yahoo.co.in

Received: June 26, 2016; Revised received: May 20, 2017; Accepted: September 30, 2017

Abstract: The utilization of plastic carry bags in our modern life is increasing every year and also increasing pressure on safe disposal of these bags. Worldwide the disposal of these kinds of plastic wastes is becoming serious issue due to their non-degradable nature. The main aim of this study is to exploit the potential of waste plastic carry bags for the production of plastic crude oil by using non-electric pyrolytic unit. The heat required for pyrolysis process supplied from biomass gas stove and coconut shell used as combustible fuel. To optimize the heating conditions for higher plastic crude oil recovery, different quantities of coconut shell were utilized and the maximum recovery of plastic crude oil was recorded. The yield of crude oil ranged from 34.5 to 40.7 per cent for the reaction temperature ranged from 457 to $517^{\circ} \mathrm{C}$. For $4 \mathrm{~kg}$ fuel supplied as heating source, the crude oil recovered was 40.7 per cent at a reaction temperature of $486{ }^{\circ} \mathrm{C}$ and residence time of $58 \mathrm{~min}$. The calorific value of the waste plastic carry bags and plastic crude oil was found to be 34.4 and $38.6 \mathrm{MJ} / \mathrm{kg}$, respectively.

Keywords: Biomass gas stove, Coconut Shell, Crude oil, Pyrolysis, Waste plastic carry bags

\section{INTRODUCTION}

Plastics are non-biodegradable polymers and it plays important role in our daily usage. An estimate shows that the global plastic production is growing at a rate of 4 per cent per year (Sriningsih, et al., 2014). Plastic carry bags are most widely used among other plastics. The consumption of plastic carry bags is fast with stable growth due to relatively low cost, and durability (Singhabhandhu and Tezuka, 2010). In India, approximately 12 Million tonnes plastic products are consumed every year, which is expected to rise further (CPCB, 2015). Consequently, increased usages of plastic bags would lead to serious environmental challenges due to large quantities and safe disposal problems.

Conventional waste plastics recycling methods (viz., landfill and incineration) are seems to be inadequate or do not meet out the current environmental regulations (Syamsiro et al., 2013). Disposing of plastic wastes by landfilling is not a suitable option due to high cost and poor biodegradability. Increasing cost and decreasing space of landfills are forcing considerations of alternative options for plastic solid waste disposal (Zia et al., 2007). Due to release of harmful gases like dioxins, hydrogen chloride, airborne particles, and carbon dioxide, incineration of polymer possesses serious air pollution problems. Worldwide research is being done for searching suitable ecofriendly technology for safe disposal of these non-degradable plastic bags. Therefore, alternative methods such as recycling and recovery methods of plastic solid wastes can be economically and environmentally viable (Howard, 2002), which involve pyrolysis of plastics into fuels, have been introduced not only for waste reduction but also for fuel production (Syamsiro et al., 2014).

Pyrolysis is the process of thermal degradation of wastes at elevated temperature in the absence of oxygen to produce various fuels (solid, liquids and gaseous). By keeping aforementioned points, an attempt was made to convert the waste plastic bags into fuel crude oil through pyrolytic process.

\section{MATERIALS AND METHODS}

Characterization of selected wastes: Waste plastic carry bags were collected from Kurudampalayam village, Coimbatore district, Tamil Nadu, India. The collected waste plastics were cleaned and then, size reduced into smaller pieces $(5-8 \mathrm{~cm})$. Coconut shell was used as combustible fuel in the biomass gas stove. The reasons for selection of coconut shell as combustible fuel in biomass gas stove were higher calorific value $(21.6 \mathrm{MJ} / \mathrm{kg})$ and less ash content $(1.93 \%)$ than to other biomass feedstocks. The proximate composition of coconut shell and waste plastic carry bags were studied using standard methods (fixed carbon: ASTM D3172, ash: ASTM D3174 and volatile matter: ASTM D3175). The elemental composition of the samples was determined using an elemental analyzer (Thermo Fisher, Flash 2000, USA) coupled with an auto sampler and data processor by following ASTM D 
3174-76 procedure. The calorific value of tested samples was determined in a bomb calorimeter (M/s. Aditya, India) as per ASTM D 5001 procedure (ASTM, 1983).

Description of biomass gas stove:

\begin{tabular}{|c|c|}
\hline Working principle & - $\quad$ Updraft gasification \\
\hline Feedstock & $\begin{array}{l}\text { Woodchips, agricultural } \\
\text { residues, dry leaves, } \\
\text { barks }\end{array}$ \\
\hline Construction material & $\begin{array}{l}\text { - Clay, sand and paddy } \\
\text { husk }\end{array}$ \\
\hline $\begin{array}{l}\text { Diameter of biomass } \\
\text { gas stove }\end{array}$ & $-\quad 0.29 \mathrm{~m}$ \\
\hline $\begin{array}{l}\text { Height of biomass } \\
\text { gas stove }\end{array}$ & - $\quad 0.63 \mathrm{~m}$ \\
\hline Iron grate & $\begin{array}{l}\text { - Fixed at } 0.05 \mathrm{~m} \text { from the } \\
\text { base of the reactor }\end{array}$ \\
\hline $\begin{array}{l}\text { Rate of fuel con- } \\
\text { sumption }\end{array}$ & $-\quad 4-5 \mathrm{~kg} / \mathrm{h}$ \\
\hline Thermal efficiency & $-25 \%$ \\
\hline Flame temperature & $-\quad 600-700^{\circ} \mathrm{C}$ \\
\hline Saving in fuel & $\begin{array}{l}\text { - } 15-18 \% \text { over } \\
\text { conventional wood } \\
\text { stoves }\end{array}$ \\
\hline Saving in time & $\begin{array}{l}\text { - } \quad 40 \% \text { over conventional } \\
\text { wood stoves }\end{array}$ \\
\hline
\end{tabular}

Pyrolysis of waste plastic carry bags in non-electric horizontal pyrolytic unit: A $300 \mathrm{~g}$ non-electric horizontal pyrolytic unit (Fig. 1) was developed to carry out this study. The material used for fabrication of this unit was mild steel. One end of pyrolytic unit was used as inlet port and other was connected to 1.3 $\mathrm{cm}$ diameter pipe. A biomass gas stove is used as heat source for this pyrolysis process. During the experiments, plastic samples were fed into pyrolytic unit through the inlet port. In order to create pyrolysis conditions in the unit, nitrogen gas was purged through the inlet port for $15 \mathrm{~min}$ and then, inlet port was tightly closed. Heat is supplied from biomass gas stove by burning known quantity of coconut shell. There were three steps involved in this conversion process. Firstly, sufficient heat was supplied to pyrolytic unit, secondly the vapors were generated from plastic bags in the unit under pyrolysis conditions and finally, these vapors were cooled through condenser to yield the plastic crude oil. 3, 4 and $5 \mathrm{~kg}$ coconut shell were used in the experiments. The optimal quantity of combustion fuel required for maximum fuel crude oil yield was determined. The time required for complete conversion of plastic waste into final products is refereed as residence time. The maximum reaction temperature, residence time and yield of different products like crude oil, gas and solid residue were recorded and reported as the average value of the three replications.
The specific gravity and calorific value (ASTM D 5001) of the produced plastic crude oil were estimated.

\section{RESULTS AND DISCUSSION}

Characterization of combustible fuel and waste plastic carry bags: Table 1 shows the properties of tested biomass and waste samples. The volatile matter and ash content of the combustible fuel (i.e. coconut shell) used in the biomass gas stove was found to be 78.4 and 1.93 per cent, respectively. The proximate composition of coconut shell was on par with the results reported by Ewansiha et al. (2012). The carbon, hydrogen and oxygen content of the selected biomass sample were determined as 48.14, 5.88 and 43.29 per cent, respectively. Calorific value of coconut shell was found to be $21.6 \mathrm{MJ} / \mathrm{kg}$. These results were concurrence with the results reported by Liyanage and Pieris (2015).

Higher volatile content and lower ash content of the feedstock favoured the thermochemical conversion technologies viz., combustion, pyrolysis and gasification (Amutio et al., 2012). Pyrolysis is one of the thermochemical conversion technologies used to produce three different products (solid, liquid and gas) depends on reaction temperature. Slow pyrolysis has traditionally been used for the production of charcoal with the temperature range of $250-400^{\circ} \mathrm{C}$ and fast pyrolysis at moderate temperatures $\left(400-650^{\circ} \mathrm{C}\right)$, has generally been used to obtain high yield of liquid products (up to 70\% wt) (Jahirulet al., 2012). An increase in pyrolysis temperature increases the yield of liquid and gaseous products and decreases char production (Chen et al., 2014). Since, the selected waste plastic carry bags had higher volatile matter $(91.62 \%)$ and lower ash content $(6.57 \%)$, so these are suitable for pyrolysis process. These results were match with the results reported by Sharuddin et al. (2016). The higher amount of carbon (79.75\%) and hydrogen (13.4\%) indicate that the selected waste plastic carry bags were well suitable for plastic crude oil production, which can be further processed to obtain hydrocarbon fuels. The test results were found to be concurrence with Sharma et al., (2014). There was lesser amount of oxygen $(5.13 \%)$ present in the selected waste plastic carry bags and it may be due to the fillers and other ingredients added in the manufacturing processes.

Plastic crude oil production from waste plastic carry bags: The pyrolysis of waste plastic carry bags was carried out in the pyrolytic unit (Fig. 2) and yields of three different products, i.e., crude oil, solid residue and pyrolytic gas were recorded by varying the quantities of coconut shell $(3,4$, and $5 \mathrm{~kg})$ in the biomass gas stove. Increase in quantities of coconut shell and effect of different quantities of coconut shell on crude oil yield were studied. The yields of crude oil, solid residue and gas produced from plastic bags at different 
Table 1. Characterization of the selected wastes.

\begin{tabular}{|c|c|c|c|c|c|c|c|c|c|}
\hline \multirow[t]{2}{*}{ Samples } & \multicolumn{3}{|c|}{ Proximate composition, $\%$} & \multicolumn{5}{|c|}{ Elemental composition, $\%$} & \multirow{2}{*}{$\begin{array}{c}\text { Calorific } \\
\text { value, } \mathrm{MJ} / \\
\mathrm{kg}\end{array}$} \\
\hline & $\begin{array}{l}\text { Volatile } \\
\text { Content }\end{array}$ & $\begin{array}{c}\text { Ash } \\
\text { content }\end{array}$ & $\begin{array}{c}\text { Fixed } \\
\text { carbon }\end{array}$ & $\mathbf{C}$ & $\mathbf{H}$ & $\mathbf{N}$ & $\mathbf{S}$ & $\mathbf{O}$ & \\
\hline Coconut shell & 78.40 & 1.93 & 19.67 & 48.14 & 5.88 & 0.6 & - & 43.29 & 21.6 \\
\hline $\begin{array}{l}\text { Waste plastic } \\
\text { carry bags }\end{array}$ & 91.62 & 6.57 & 1.81 & 79.75 & 13.40 & 0.3 & - & 5.13 & 34.4 \\
\hline
\end{tabular}

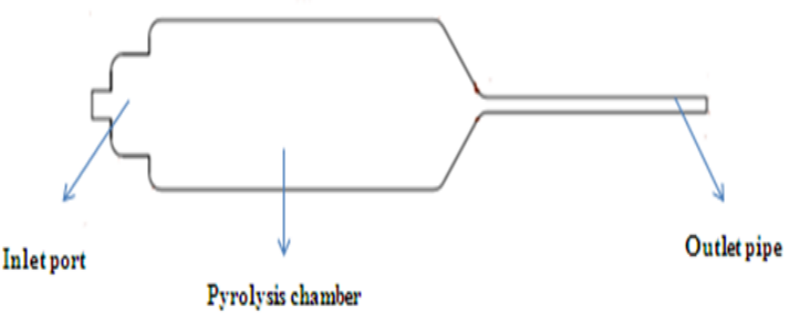

Fig. 1. Schematic diagram of non-electric horizontal pyrolytic unit.

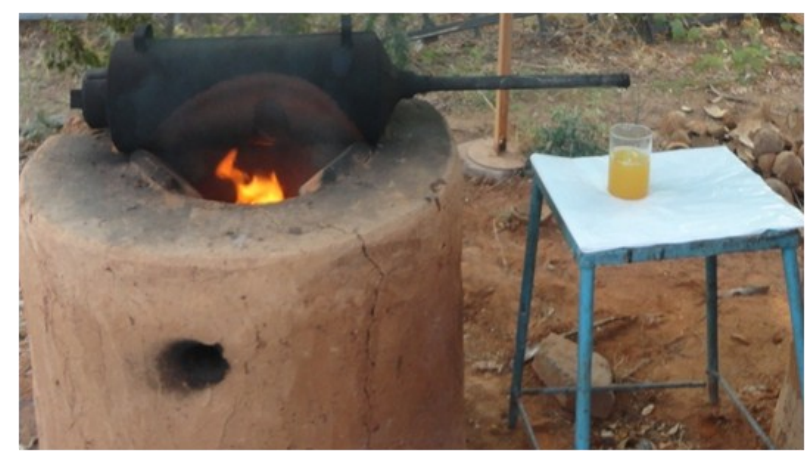

Fig. 2. Pyrolysis of waste plastic carry bags.

quantities of fuel supplied were ranged from 34.5 to $40.7,9.5$ to 19.2 and 46.3 to 51.3 per cent, respectively (Fig.3). These results were coincidence with the results reported by Sachin Kumar and Singh (2013). The reaction temperature of pyrolysis process was increased with increased fuel supplied, whilst the residence time was in decreasing trend with increasing fuel supply. From the fig. 4, it is observed that the recovery of plastic crude oil was increased with gradual increase of reaction temperature from 457 to $486^{\circ} \mathrm{C}$ and then gradually decreased with further increase in temperature, whilst the yield of non-condensable gas was in increasing trend with increasing reaction temperature. For all experimental trials, the crude oil and the non-condensable gases were observed as major constituents than that of solid residue. The crude oil yield of 40.7 per cent at a reaction temperature of $486^{\circ} \mathrm{C}$ with residence time of $58 \mathrm{~min}$ for $4 \mathrm{~kg}$ fuel supplied was found to be highest than that of 3 and $5 \mathrm{~kg}$ fuel supplied. Variation in the product yield might be due to the resultant reaction temperature of the experiment. Highest reaction temperature $\left(514^{\circ} \mathrm{C}\right)$ with residence time of $45 \mathrm{~min}$ was attained during $5 \mathrm{~kg}$ fuel supply, but yielded 39.2 per cent of crude oil, whilst 34.5 per cent recovered at

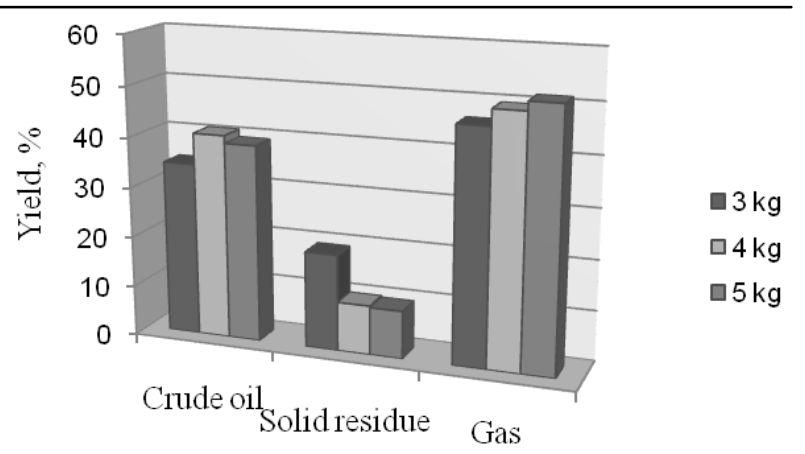

Fig. 3. Effect of combustible fuel used on yields of final products.

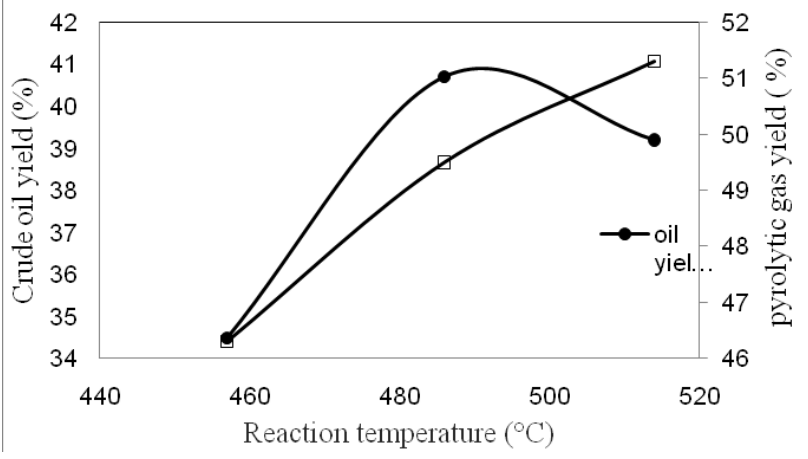

Fig. 4. Effect of reaction temperature on yields of oil and gas.

$457^{\circ} \mathrm{C}$ with residence time of $72 \mathrm{~min}$ for $3 \mathrm{~kg}$ of fuel supplied. This confirmed that the quantity of fuel supplied and reaction temperature had influences on pyrolysis reaction rate, which directly reflect on yield of final products. Higher reaction temperature helps in quick cracking down of the chemical bonds, which may led to speed up the reaction rate and resulted in lower residence time. Specific gravity and calorific value of plastic crude oil were determined as 0.79 and $38.6 \mathrm{MJ} / \mathrm{kg}$ respectively, which is similar to the results reported by Panda and Singh (2013). From these results, it is observed that the fuel properties of plastic crude oil match with the properties of petroleum fuels.

\section{Conclusion}

The present study revealed that the selected waste plastic carry bags were suitable for the production of plastic crude oil through pyrolysis process by using non-electric pyrolytic unit. Three different quantities of coconut shell were used $(3,4$ and $5 \mathrm{~kg}$ ) in a biomass gas stove in a batch mode and its effect on reaction temperature, residence time and yields of pyrolytic 
products was studied. It was found that the main operational parameters viz., reaction temperature and residence time had influenced on yields of final products. The highest crude oil yield (40.7\%) was obtained at $486^{\circ} \mathrm{C}$ when $4 \mathrm{~kg}$ fuel was supplied. The crude oil yield was decreased further increase in fuel supply, whilst residence time decreased with increase in reaction temperature. The specific gravity and calorific value of plastic crude oil was found to be 0.79 and $38.6 \mathrm{MJ} / \mathrm{kg}$, respectively. The plastic crude oil recovered from waste plastic carry bags may be a good candidate for the production of fuels by adapting suitable fractioning process. It has been shown that a simple batch pyrolysis method is the useful method of waste to energy recovery process.

\section{REFERENCES}

Amutio, M., Lopez, G., Artetxe, M., Elordi, G., Olazar, M. and Bilbao, J. (2012). Influence of temperature on biomass pyrolysis in a conical spouted bed reactor. Resources, Conservation and Recycling, 59: 23- 31.

ASTM (1983). American Society for Testing and Materials. Standard methods for testing Small clear specimen. ASTM 143-83. Philadelphia Pa. 48-105.

Chen, T., Yaxin, Z., Hongtao, W., Wenjing, L., Zeyu, Z., Yuancheng, Z. and Lulu, R. (2014). Influence of pyrolysis temperature on characteristics and heavy metal adsorptive performance of biochar derived from municipal sewage sludge. Bioresource Technology, $16: 47$ -54 .

CPCB(2015). Central Pollution Control Board. Status of implementation of plastic waste management (PWM). November 2015.

Ewansiha, C.J., Ebhoaye, J.E., Asia, I.O., Ekebafe, L.O. and Ehigie, C. (2012). Proximate and Mineral Composition of Coconut (Cocos Nucifera) Shell. Int. J. Pure Appl. Sci. Technol., 13(1): 57-60.

Howard, G.T. (2002). Biodegradation of polyurethane: A review. International Biodeterioration and Biodegradation, 49 (1): 245-252.

Jahirul, M.I., Rasul, M.G., Chowdhury, A.A. and Ashwath. N. (2012). Biofuels Production through Biomass
Pyrolysis - A Technological Review. Energies, 5: 49525001.

Liyanage, C.D. and Pieris, M. (2015). A physico-chemical analysis of coconut shell powder. Procedia Chemistry, 16: $222-228$

Panda, A. K. and Singh, R. K. (2013). Experimental optimization of process for the thermo-catalytic degradation of waste polypropylene to liquid fuel. Advances in Energy Engineering, 1(3): 4-84.

Sachin Kumar and Singh, R. K. (2013). Thermolysis of High -Density Polyethylene to petroleum products. Journal of Petroleum Engineering, 2013: 1-7.

Sharma, B. K., Moser, B. R., Vermillion, K. E., Doll, K. M. and Rajagopalan, N. (2014). Production, characterization and fuel properties of alternative diesel fuel from pyrolysis of waste plastic grocery bags. Fuel Processing Technology, 122: 79-90.

Sharuddin, S.D.A., Abnisa, F., Daud, W.M.A.W. and Aroua, M.K. (2016). A review on pyrolysis of plastic wastes. Energy Conservation and Management, 115: 308-326.

Singhabhandhu, and Tezuka, T. (2010). The waste-to-energy framework forintegrated multi-waste utilization: Waste cooking oil, waste lubricatingoil, and waste plastics. Energy, 35: 2544-2551.

Sriningsih, W., Saerodji, M.G., Trisunaryanti, W., Triyono, Armunanto, R., and Falah, I.I. (2014). Fuel Production from LDPE Plastic Waste over Natural Zeolite Supported Ni, Ni-Mo, Co and Co-Mo Metals. Procedia Environmental Sciences, 20: 215-224.

Syamsiro, M., Harwin, S., Norsujianto, T., Noviasri, P., Cheng, S., Alimuddin, Z. and Yoshikawa, K. (2014). Fuel Oil Production from Municipal Plastic Wastes in Sequential Pyrolysis and Catalytic Reforming Reactors. Energy Procedia, 47: 180-188.

Syamsiro, M., Hu, W., Komoto, S., Cheng, S., Noviasri, P., Prawisudha, P. and Yoshikawa, K. (2013). Co-production of liquid and gaseous fuels from polyethylene and polystyrene in a continuous sequential pyrolysis and catalytic reforming system. Energy and Environment Research, 3(2): 90-106.

Zia, K.M., H.N. Bhatti, I.A. Bhatti. 2007. Methods for polyurethane and polyurethane composites, recycling and recovery: A review. Reactive \& Functional Polymers, 67 (8): 675-692. 